\title{
Poly [ADP-Ribose] Polymerase 3
}

National Cancer Institute

\section{Source}

National Cancer Institute. Poly [ADP-Ribose] Polymerase 3. NCI Thesaurus. Code C147980.

Poly [ADP-ribose] polymerase 3 (533 aa, $\sim 60 \mathrm{kDa}$ ) is encoded by the human PARP3 gene.

This protein plays a role in DNA repair and protein modification. 